\title{
The influence of the climatic potential of Western Siberia on the ecological plasticity of spring barley varieties
}

\author{
Lyudmila Yakubyshina ${ }^{1,{ }^{*}}$ and Olga Shakhova ${ }^{1}$ \\ ${ }^{1}$ FSBEI HE State Agrarian University of the Northern Trans-Urals, Russia
}

\begin{abstract}
Modern technologies of cultivation of crops directly depend on climatic parameters: temperature, amount of precipitation and their distribution by months. Crop productivity can be controlled by studying and understanding the influence of the climatic potential of Western Siberia. This paper is devoted to its features. Analysis of the influence of abiotic factors on the yield of spring barley for the period 2014-2019 showed that: the sum of effective temperatures of $1500^{\circ} \mathrm{C}$, necessary for the growth and development of plants, accumulates annually; the harvest is formed by atmospheric precipitation for five months (May-September), which is $60 \%$ of the average annual norm with fluctuations from year to year from 12.1 to $38.0 \%$ (303.6-373.7 mm); the hydrothermal coefficient for May-July has an average effect on the yield of the Abalak, Acha, Vorsinsky 2 varieties (the coefficient of variation of the yield is $11.9,14.9$ and $16.3 \%$, respectively) and significant effect on the crops of the Chelyabinsky 99 variety (the coefficient of variation is $25.7 \%$ ). The Abalak and Chelyabinsky 99 varieties turned out to be more responsive to changes in growing conditions, as evidenced by the values of the regression coefficient (bi) (1.04 and 1.48) exceeding unity. The Acha and Vorsinsky 2 varieties are characterized by a weak response to improved growing conditions.
\end{abstract}

\section{Introduction}

The natural and climatic conditions of Western Siberia are considered to be quite a favorable region for the cultivation of grain crops; spring barley occupies a significant part of the sown area and remains one of the main forage crops [1]. Long-term agronomic practice has shown that the variety is of particular importance in increasing the yield and quality of grain [2]. The success of creating new varieties depends on the study of the source material. For many years, about seven thousand collection varieties of spring barley from different regions of Russia and foreign countries have been studied. The varietal technology and production of food grains and seeds have been improved [3].

The main feature of the Siberian climate is that in some years, meteorological elements are unfavorable for the formation of high quality grain. Due to the short frost-free period and cold wet weather in August, the growing season is longer in some years, and the seeds

* Corresponding author: ya.mila80@mail.ru 
do not have time to ripen, which leads to a decrease in quality [4]. Spring barley needs warm (the sum of active temperatures is above $10^{\circ} \mathrm{C}$ ) from $960-1450^{\circ} \mathrm{C}$, depending on the variety.

The development of adaptive varieties that are resistant to various stresses has been and remains an urgent problem, especially since the set of negative factors is expanding due to climate change $[5,6,7]$. Evaluation of varieties in ecological variety testing will make it possible to single out from a large number of created varieties with high potential productivity varieties with the greatest degree of adaptation to the conditions of a particular region $[8,9]$.

Thus, the issue of crop productivity management does not lose its relevance, especially in the era of climate change.

\section{Materials and methods}

Objective of the research: to study the influence of the climatic potential of Western Siberia on the ecological plasticity of spring barley varieties.

The data were obtained on the basis of analysis and generalizations of materials from the Yalutorovskiy State Variety Testing Site (SVTS) for 2014-2019.

Four varieties of spring barley included in the register of breeding achievements in $10^{\text {th }}$ (West Siberian) region were studied: Acha, Vorsinsky 2, Chelyabinsky 99, and Abalak (standard).

Agroclimatic indicators by years of research are shown in Table 1.

In Western Siberia (northern forest-steppe of the Tyumen region), there is a wide range of crops suitable for cultivation, which is limited by the total need for heat and the sum of effective temperatures (May-September), which varied over the years of research from 1511.0 to $2520.1^{\circ} \mathrm{C}$.

Based on the analysis of the complex indicator of the Selyaninov hydrothermal coefficient (HTC), the studied weather conditions in the northern forest-steppe of the Tyumen region were not the same: 2014, 2015, 2018, and 2019 - wet; 2016 and 2017 slightly arid.

Table 1. Agroclimatic indicators in 2014-2019, according to the branch of the FSBI "Hydrometeorological Center of Russia" in the Tyumen region.

\begin{tabular}{|l|c|c|c|c|c|c|}
\hline \multicolumn{1}{|c|}{ Indicators } & $\mathbf{2 0 1 4}$ & $\mathbf{2 0 1 5}$ & $\mathbf{2 0 1 6}$ & $\mathbf{2 0 1 7}$ & $\mathbf{2 0 1 8}$ & $\mathbf{2 0 1 9}$ \\
\hline $\begin{array}{l}\text { Average annual air } \\
\text { temperature, }{ }^{0} \mathrm{C}\end{array}$ & +1.2 & +3.4 & +3.8 & +1.6 & +1.1 & +2.2 \\
\hline $\begin{array}{l}\text { Maximum air temperature, } \\
{ }^{0} \mathrm{C}\end{array}$ & +32.0 & +33.3 & +31.5 & +32.0 & +32.1 & +31.3 \\
\hline $\begin{array}{l}\text { Minimum air temperature, } \\
{ }^{0} \mathrm{C}\end{array}$ & -38.0 & -37.7 & -34.8 & -40.9 & -35.3 & -40.8 \\
\hline Annual precipitation, mm & 522.5 & 523.0 & 440.7 & 392.1 & 610.8 & 436.9 \\
\hline $\begin{array}{l}\text { The amount of precipitation } \\
\text { for the period May- } \\
\text { September, mm }\end{array}$ & 303.6 & 373.7 & 253.8 & 253.6 & 355.2 & 316.7 \\
\hline \begin{tabular}{l} 
Soil freezing depth, cm \\
\hline Snow depth, cm of effective
\end{tabular} & 104 & 76 & 72 & 69 & 150 & 95 \\
\hline $\begin{array}{l}\text { The sum of } \\
\text { temperatures for the period } \\
\text { May-September, 0C }\end{array}$ & 2171.4 & 2249.5 & 2520.1 & 2225.5 & 2164.2 & 1511.0 \\
\hline $\begin{array}{l}\text { Hydrothermal coefficient } \\
\text { for the period May- } \\
\text { September }\end{array}$ & 1.4 & 1.6 & 1.0 & 1.1 & 1.6 & 2.1 \\
\hline
\end{tabular}


The arable land used by the Yalutorovskiy SVTS is occupied by leached chernozems with characteristics and properties typical of Western Siberia. The humus content in the arable layer $(0-30 \mathrm{~cm})$ varies from 7.65 to $9.05 \%$, deeper it decreases from 4.41 to 0.72 $0.54 \%$. The gross content of nitrogen and phosphorus in the arable layer is $0.43-0.44 \%$ and $0.16-0.18 \%$, and their reserves reach 20 and $8.5 \mathrm{t} / \mathrm{ha}$, respectively $[10,11,12,13]$.

The technology of barley cultivation includes: early spring harrowing at the onset of physical ripeness of the soil in 2-3 traces across the direction of the main cultivation; presowing tillage; before sowing - incision ammonium nitrate for the planned yield of $5 \mathrm{t} / \mathrm{ha}$; sowing with a seeding rate of 5.5 million viable seeds per hectare (Table 2); harvesting, which was carried out in the phase of full ripeness by direct combining; plowing for 20-22 $\mathrm{cm}$.

Table 2. Dates of sowing barley, 2014-2019.

\begin{tabular}{|l|c|c|c|c|c|}
\hline \multicolumn{7}{|c|}{ Dates of sowing in 2014-2019 } \\
\hline 2014 & 2015 & 2016 & 2017 & 2018 & 2019 \\
\hline 18.05 & 17.05 & 16.05 & 17.05 & 15.05 & 19.05 \\
\hline
\end{tabular}

\section{Results}

In the structure of sown areas (Table 3) of agricultural enterprises of the Tyumen region, barley occupies from $21 \%(2017-2019)$ to $25 \%$ (2015).

Table 3. Sown area of grain crops, 2014-2019 (according to the Department of the Agro-Industrial Complex of the Tyumen Region).

\begin{tabular}{|c|c|c|c|c|c|}
\hline \multicolumn{7}{|c|}{ Sown area, thousand hectares } \\
\hline 2014 & 2015 & 2016 & 2017 & 2018 & 2019 \\
\hline 144.71 & 163.87 & 141.71 & 136.92 & 128.30 & 126.49 \\
\hline
\end{tabular}

Temperature features of May 2014-2019 led to sufficient warming of the soil cover and allowed sowing spring wheat, barley and oats traditionally in the third decade of the month. May 2018 was the coldest of the five years of observation $\left(3.4^{\circ} \mathrm{C}\right.$ colder than the multiyear average). In June, this dynamics remained, the average temperature was $2.5^{\circ} \mathrm{C}$ below the norm. July, on the other hand, was dry and hot.

In 2014, the July temperature regime was $3.1^{\circ} \mathrm{C}$ colder than the norm. These fluctuations were influenced by the course of the phases of development of grain crops, which was reflected in the overall yield.

In the general dynamics of temperature in August 2014-2018, the coldest were 2015 and 2018 , in others - the regime was comfortable for grain crops and slightly warmer than the norm: by $1.5^{\circ} \mathrm{C}-2014$ and $2019,2.9^{\circ} \mathrm{C}-2016,0.6^{\circ} \mathrm{C}-2017$

The temperature features of August were not the same.

Another indicator, the sum of effective temperatures, gives more information about the growth and development of grain crops (Table 4). The $1500^{\circ} \mathrm{C}$ required for plants accumulated during all the years of research. However, in 2016, the maximum accumulation of the sum of effective temperatures was noted $-2520.1^{\circ} \mathrm{C}$, the summer was moderately warm in the first months, hot in the middle, and ended with a sharp cooling at the end of August. 
Table 4. Sum of effective temperatures, 2014-2019.

\begin{tabular}{|c|c|c|c|c|c|c|}
\hline \multirow{2}{*}{ Years } & \multicolumn{6}{|c|}{ Sum of effective temperatures, ${ }^{\mathbf{0} C}$} \\
\cline { 2 - 7 } & May & June & July & August & September & $\begin{array}{c}\text { May- } \\
\text { September }\end{array}$ \\
\hline 2014 & 399.9 & 501.0 & 455.7 & 561.1 & 253.7 & 2171.4 \\
\hline 2015 & 415.4 & 600.0 & 508.4 & 409.2 & 316.5 & 2249.5 \\
\hline 2016 & 372.0 & 516.0 & 598.3 & 660.3 & 373.5 & 2520.1 \\
\hline 2017 & 310.0 & 507.0 & 545.6 & 523.9 & 339.0 & 2225.5 \\
\hline 2018 & 244.9 & 432.0 & 660.3 & 480.5 & 346.5 & 2164.2 \\
\hline 2019 & 96.0 & 391.0 & 475.0 & 320.0 & 189.0 & 1511.0 \\
\hline $\begin{array}{c}2014- \\
2019\end{array}$ & 306.4 & 491.1 & 540.6 & 492.5 & 303.0 & 2140.3 \\
\hline perennial & 378.5 & 560.8 & 647.4 & 575.1 & 343.6 & 2505.3 \\
\hline
\end{tabular}

The soil moisture regime depends on the amount of precipitation and their distribution throughout the year. In the northern forest-steppe of the Tyumen region, the average annual precipitation rate is $450.0 \mathrm{~mm}$ (Table 5). However, it fluctuates over the years and seasons. For seven autumn-winter-early spring months (October-April), the average annual precipitation is $40 \%$ of the annual norm $(179.0 \mathrm{~mm})$ with an annual amplitude of 29.0 to $42.0 \%$.

In May-September, the average precipitation is $271 \mathrm{~mm}(60 \%$ of the average annual) with annual fluctuations from 12.1 to $38.0 \%(303.6-373.7 \mathrm{~mm})$. The harvest is formed by atmospheric precipitation for five months and largely depends on the technical solutions of specialists during this period.

Table 5. Dynamics of precipitation, 2014-2019.

\begin{tabular}{|c|c|c|c|c|c|c|}
\hline \multirow{2}{*}{ Years } & \multicolumn{7}{|c|}{ Precipitation, mm } \\
\cline { 2 - 7 } & $\begin{array}{c}\text { average } \\
\text { annual } \\
\text { amount }\end{array}$ & $\begin{array}{c}\text { on } \\
\text { average } \\
\text { for 2014- } \\
\mathbf{2 0 1 9} \%\end{array}$ & $\begin{array}{c}\text { to average } \\
\text { long- } \\
\text { term,\% }\end{array}$ & $\begin{array}{c}\text { including } \\
\text { May- } \\
\text { September }\end{array}$ & $\begin{array}{c}\text { on } \\
\text { average } \\
\text { for 2014- } \\
\mathbf{2 0 1 9 , \%}\end{array}$ & $\begin{array}{c}\text { to } \\
\text { average } \\
\text { long- } \\
\text { term,\% }\end{array}$ \\
\hline 2014 & 522.5 & 105.0 & 116.1 & 303.6 & 98.5 & 112.0 \\
\hline 2015 & 523.0 & 105.0 & 116.1 & 373.7 & 121.3 & 138.0 \\
\hline 2016 & 440.7 & 88.5 & 98.0 & 253.8 & 82.4 & 93.7 \\
\hline 2017 & 392.1 & 78.8 & 87.1 & 88.5 & 97.9 & 93.6 \\
\hline 2018 & 610.8 & 122.7 & 135.7 & 355.2 & 115.3 & 131.1 \\
\hline 2019 & 436.9 & 89.6 & 97.0 & 281.9 & 91.5 & 104.0 \\
\hline $\begin{array}{c}2014- \\
2018\end{array}$ & 487.7 & 100.0 & - & 308.0 & 100.0 & - \\
\hline $\begin{array}{c}\text { long- } \\
\text { term }\end{array}$ & 450.0 & - & 100.0 & 271.0 & - & 100.0 \\
\hline
\end{tabular}

Maximum atmospheric precipitation - $142.0 \mathrm{~mm}$ according to the long-term average indicator (52\% of the average for May-September) - falls in July-August. Physical properties of the soil, such as soil density, porosity of aeration and capillary porosity, also play an important role in the formation of spring moisture reserves in the soil $[14,15]$. These features of precipitation give reason to recommend programming technological solutions with a more efficient use of this maximum due to the selection of appropriate varieties, optimal sowing times and other methods.

The amount of precipitation in May-June ranged from 53.5 in $2017(\mathrm{HTC}=0.80)$ to $155.2 \mathrm{~mm}$ in 2018 (HTC=4.0).

For the period 2014-2019, 2016 and 2017 were slightly arid; 2014 - fairly humid; 2015 wet; 2018 and 2019 - perhumid. 
The most favorable conditions for the growth and development of the studied varieties were formed in 2014 and 2019. The environmental conditions index was positive: from 0.31 to 0.86 ; the worst conditions were noted in 2016 - - 0.97 (Table 6).

Table 6. Barley yield, 2014-2019.

\begin{tabular}{|c|c|c|c|c|c|c|c|c|c|}
\hline \multirow[b]{2}{*}{ Varieties } & \multicolumn{7}{|c|}{ Years } & \multirow{2}{*}{ 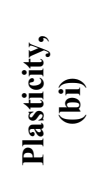 } & \multirow{2}{*}{ 昰 } \\
\hline & $\stackrel{4}{\overrightarrow{4}}$ & 尔 & 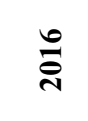 & 둘 & $\stackrel{\infty}{\text { ฮై }}$ & हें & 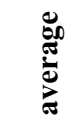 & & \\
\hline Abalak (st) & 4.48 & 3.99 & 2.91 & 4.31 & 3,88 & 4.84 & 4.07 & 1.04 & 0.06 \\
\hline Acha & 3.82 & 3.63 & 3.03 & 3.77 & 4,06 & 4.37 & 3.78 & 0.69 & 0.04 \\
\hline Vorsinsky 2 & 4.69 & 3.98 & 3.01 & 3.58 & 3,72 & 4.19 & 3.86 & 0.78 & 0.13 \\
\hline Chelyabinsky 99 & 3.72 & 3.79 & 2.66 & 3.13 & 3,77 & 5.52 & 3.77 & 1.48 & 0.18 \\
\hline $\begin{array}{l}\text { Environmental } \\
\text { conditions index }\end{array}$ & 0.31 & -0.02 & -0.97 & -0.17 & $-0,01$ & 0.86 & & & \\
\hline
\end{tabular}

The linear regression coefficient of the yield of varieties and breeding lines $b i$ shows their response to changes in growing conditions. The Abalak (1.04) and Chelyabinsky 99 (1.48) varieties were more responsive to changes in growing conditions; their regression coefficient (bi) was higher than one. The Acha and Vorsinsky 2 varieties had a regression coefficient of less than one, i.e. they are characterized by a weak response to improved growing conditions. Stability $\left(\sigma_{\mathrm{d}}^{2}\right)$ is an important parameter in the evaluation of varieties and breeding lines. The lower the $\sigma_{\mathrm{d}}^{2}$ indicator, the smaller the difference between the theoretical and actual yield, and hence the higher stability of the analyzed feature in time and space. High stability was observed in all studied varieties (0.04-0.18). The reaction of barley varieties to environmental conditions is clearly shown in Figure 1.

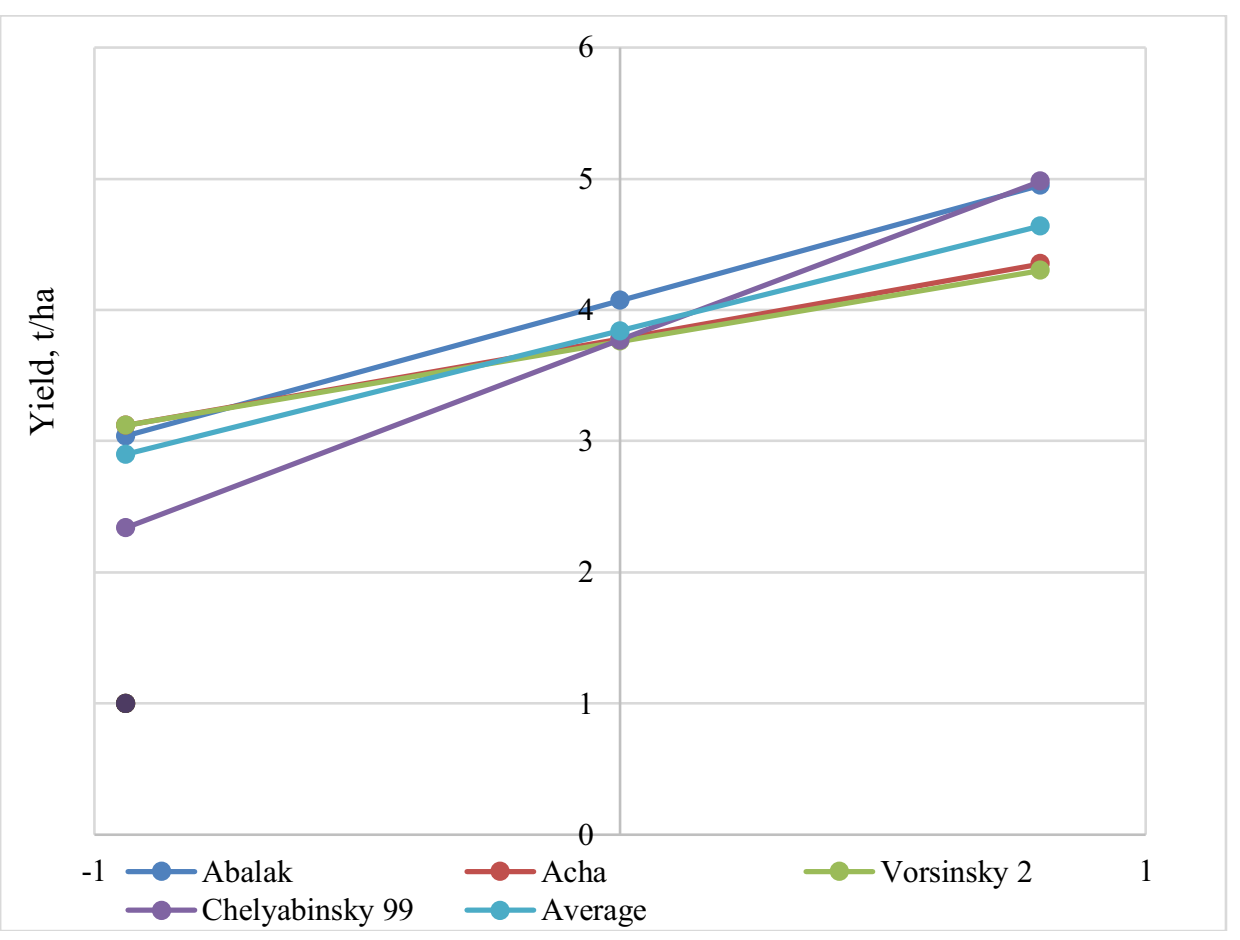

Fig. 1. Regression lines of yield of spring barley varieties, 2014-2019. 
The Abalak standard variety has higher yields than the average for the experiment due to the higher average yields over the years of the study. The rest of varieties have regression lines below the average.

The magnitude of the slope of the regression lines provides visual information about the behavior of varieties relative to each other and in comparison with the average response of varieties to changes in growing conditions.

The regression lines of the Abalak variety run parallel to the average for the experiment; this variety changes its yield with changing conditions $(\mathrm{bi}=1.04)$. The Acha and Vorsinkiy 2 varieties are characterized by low responsiveness to the improvement of growing conditions ( $\mathrm{bi}=0.69$ and 0.78 , respectively). The Chelyabinsky 99 is characterized by responsiveness to improved growing conditions, as indicated by the steep regression line. In harsh conditions, the yield of this variety was lower than others in the set, but also has a high average yield. Of the studied varieties of spring barley, Abalak and Chelyabinsky 99 stood out in terms of plasticity and stability.

Correlation and regression analysis showed that the yield of barley has an average and strong dependence on the HTC for May-July (Table 7).

Table 7. Relationship between barley yield and HTC (May-July), and its stability depending on the year.

\begin{tabular}{|l|c|c|c|c|c|}
\hline \multirow{2}{*}{ Variety } & \multirow{2}{*}{$\begin{array}{c}\text { Average } \\
\text { yield, t/ha }\end{array}$} & Correlation & \multirow{2}{*}{$\begin{array}{c}\text { Regression } \\
\text { coefficient }\end{array}$} & \multicolumn{2}{c|}{ Coefficient, \% } \\
\cline { 5 - 6 } & 4.07 & +0.66 & $\mathrm{y}=1.11 \mathrm{X}+2.44$ & 16.3 & 83.7 \\
\hline Abalak & 3.78 & +0.83 & $\mathrm{y}=0.94 \mathrm{X}+2.41$ & 11.9 & 88.1 \\
\hline Acha & 3.86 & +0.57 & $\mathrm{y}=0.82 \mathrm{X}+2.66$ & 14.9 & 85.1 \\
\hline Vorsinsky 2 & 3.77 & +0.97 & $\mathrm{y}=0.82 \mathrm{X}+2.66$ & 25.7 & 74.3 \\
\hline Chelyabinsky 99 & &
\end{tabular}

In the current weather conditions of 2014-2019, the yield of the Abalak, Acha and Vorsinsky 2 varieties changed in an average degree $(\mathrm{V}=11.9-16.3 \%)$ and ranged from 3.78 to 4.07 t/ha. The Chelyabinsky 99 variety turned out to be responsive to changes in air temperature and the amount of precipitation $(\mathrm{V}=25.7 \%)$.

\section{Conclusions}

Of the studied spring barley varieties, Abalak and Chelyabinsky 99 stood out in terms of plasticity and stability. The Chelyabinsky 99 variety $(\mathrm{V}=25.7 \%)$ was more responsive to changes in abiotic factors during the years of research.

\section{References}

1. Y.P. Loginov, A.A. Kazak, L.I. Yakubyshina, Annals of Agri Bio Research 24(1), 7681 (2019) EID: 2-s2.0-85071655469

2. A. Lyubimova, D. Eremin, IOP Conference Series: Earth and Environmental Science 403(1) (2019) doi:10.1088/1755-1315/403/1/012178

3. O.V. Shulepova, I.V. Opanasyuk, R.I. Belkina, Plant Cell Biotechnology and Molecular Biology 21(71-72), 181-192 (2020) DOI: 2-s2.0-85099661564

4. F. Ahakpaz, H. Abdi, E. Neyestani, A. Hesami, B. Mohammadi, K.N. Mahmoudi, H. Alipour, Agricultural Water 245 (2021) doi:10.1016/j.agwat.2020.106665 
5. Y.P. Loginov, A.A. Kazak, L.I. Yakubyshina, T.N. Falaleeva, S.N. Yashchenko, E.T. Yarova, Journal of Pharmaceutical Sciences and Research 10(2), 377-380 (2018) DOI: 2-s2.0-85042770895

6. D. Plaza-Bonilla, J. Lampurlanés, F.G. Fernández, C. Cantero-Martínez, European Journal of Agronomy 124 (2021) doi: 10.1016/j.eja.2021.126238

7. A.V. Lyubimova, G.V. Tobolova, D.I. Eremin, I.G. Loskutov, Vavilovskii Zhurnal Genetiki i Selektsii 24(2), 123-130 (2020) DOI: 10.18699/VJ20.607

8. A.A. Kazak, Y.P. Loginov, Annals of Agri Bio Research 24(2), 174-182 (2019) DOI: 2-s2.0-8507612158

9. L.I. Yakubyshina, A.A. Kazak, Y.P. Loginov, Ecology, Environment and Conservation 24(2), 1001-1007 (2018) DOI: 1001-1007.2-s2.0-8505884161

10. A. Iglovikov, E3S Web of Conferences 215 (2020) doi:10.1051/e3sconf/202021503006

11. A. Iglovikov, A. Motorin, A. Denisov, IOP Conference Series: Earth and Environmental Science 403(1) (2019) doi:10.1088/1755-1315/403/1/012171

12. D.I. Eremin, Eurasian Soil Science 49(5), 538-545 (2016) doi:10.1134/S1064229316050033

13. J. Hirte, W. Richner, B. Orth, F. Liebisch, R. Flisch, Science of the Total Environment 755 (2021) doi: 10.1016/j.scitotenv.2020.143453

14. A. Iglovikov, A. Motorin, E3S Web of Conferences 135 (2019) doi:10.1051/e3sconf/201913501004

15. A.S. Motorin, A.V. Bukin, A.V. Iglovikov, IOP Conference Series: Earth and Environmental Science 90(1) (2017) doi:10.1088/1755-1315/90/1/012053 